\title{
Impact of Equitization on Performance of Enterprises in Vietnam
}

\author{
TRUONG DONG LOC \\ Can Tho University - tdloc@ @ ctu.edu.vn \\ NGO MY TRAN \\ Can Tho University - nmtran@ctu.edu.vn
}

\section{ARTICLE INFO ABSTRACT}

Article history:

Received:

Aug. 162014

Received in revised form:

July 012015

Accepted:

June 202016

Keywords:

Equitization, firm performance, PSM and

DID.
The main objective of this study is to measure the impact of equitization on firm performance in Vietnam. The dataset, retrieved from the survey on enterprises conducted by the General Statistics Office of Vietnam (GSO), consists of 301 equitized state-owned firms and 127 unequitized state-owned firms during the period from 2007 to 2010. By using propensity score matching (PSM) combined with difference in differences (DID) approach, we find that equitization has positive impacts on the ratio of income before tax to total assets and the ratio of income before tax to sales. Moreover, this study reveals that debt ratio, total asset turnover, and the number of employees have significantly decreased after equitization. However, no evidence is found regarding the effect of equitization on productivity of equitized firms. 


\section{Introduction}

Since the political upheaval at the end of the $80 \mathrm{~s}$, most transition economies in the world have activated their projects of privatization. A move from state to private ownership enables firms to be more active along with their more effective performance. Despite the fact that privatization is affirmed to be a suitable approach for reforming state-owned enterprises (SOEs), a certain few of issues have yet to be clearly addressed; for example, in which specific circumstance does the privatization process become successful, or how does it influence firm performance as well as macroeconomic development of a country? Some studies have demonstrated the positive effect of privatization on the performance of businesses, whereas others accumulated evidence of the failure of privatization in several nations (Megginson \& Netter, 2001; Parker \& Kirkpatrick, 2005).

Unlike many other countries, the program for converting SOEs to joint-stock enterprises in Vietnam is called equitization, which is a major policy of the State to mobilize additional social resources for the development of manufacturing and trading activities, to generate strong motivation and dynamic management mechanism for effective use of state funds and properties, and to enhance firms' competitiveness in the integration process. The commencement of the country's equitization program was in 1992 with its pilot in some SOEs, but it was not until mid-1998 (after the promulgation of Decree No. 44/ND-CP) that it was actually implemented. By end-2015 there were a total of 4,407 equitized SOEs. According to expert opinions, the implementation of the equitization in Vietnam is more slowly progressing than had been planned.

One of the issues relating to equitization that has received much attention is how it affects firm performance. To date there have been a few issued researches investigating the equitization impact on the performance of Vietnamese businesses (Truong, Lanjouw, \& Lensink, 2006; Truong, Vo, \& Le, 2006; Ngo et al., 2015) yet focusing on the period before 2007. One crucial turning point in the progress of equitizing Vietnam's enterprises was the issuance of Decree No. 109/2007/ND-CP on June 26, 2007 as a replacement for Decree No. 187/2004/ND-CP issued on November 16, 2004. A new point of Decree No. 109/2007/ND-CP is that the equitization scheme is extended to economic groups and corporations in which the state holds $100 \%$ of charter capital. In addition, this new decree offers no more incentives to corporate income tax for equitized enterprises and no longer supports firms in tackling the problem of redundant employees 
after their conversion into joint-stock ones. These changes may affect the levels of improvement in performance of the equitized businesses.

This study attempts to provide more empirical evidence of the equitization impact on firm performance in Vietnam. Its originality is the use of rather large sample size of equitized SOEs during the period after the issuance of Decree No. 109/2007/ND-CP. Furthermore, to overcome the methodological limitations of earlier studies which also examined the equitization-performance nexus, we incorporate propensity score matching (PSM) technique with the approach of difference in differences (DID) for our empirical analyses.

\section{Review of related literature to the study}

The issue of privatization has attracted special attention of domestic and international researches due to the rapid rise in the number of privatization programs in quite a few countries, especially with transitional economies. Most empirical studies of this kind, which focused on determining the effects of privatization on the performance of enterprises (Megginson \& Netter, 2001; Parker \& Kirkpatrick, 2005), can be classified into three groups: (i) those adopting the pre-post comparison method to measure the impact of privatization on the efficiency of business operations; (ii) those using the technique of with-without comparison, and (iii) those looking into the impact of ownership structure and corporate governance on the performance of enterprises after privatization.

\section{Earlier studies adopting pre-post comparison approach}

Megginson et al. (1994) was one of the initial studies that employed the pre-post comparison approach for measuring the effect of privatization on firm performance. As such, Megginson et al. (1994) compared the mean value of each financial indicator after privatization (from $\mathrm{t}+1$ to $\mathrm{t}+3$ ) with that before privatization. Using the data for 61 enterprises in 18 countries that had been privatized over the period of 1961-1990, the authors indicated that among the firms in their sample, profitability, real sales, operating efficiency, and capital investment spending improved considerably after the process of privatization. Other than that, a plurality of studies adopted Megginson et al.'s (1994) technique to investigate the privatization impact on operating performance of many companies in various countries (Boubakri \& Cosset, 1998; La Porta \& López-de-Silanes, 1999; D’Souza \& Megginson, 2001; Dewenter \& Malatesta, 2001; Boubakri \& Cosset, 
2002; Harper, 2002; Boubakri et al., 2004). Similar to Megginson et al. (1994), these studies confirmed the positive effect of privatization on firms' performance and their financial health, detecting increases specifically in their profitability, earnings, efficiency, and investment. The firm's debt ratio, in addition, was found to reduce significantly during post-privatization periods.

\section{Earlier studies adopting with-without comparison approach}

Upon utilizing the method of with-without comparison, a few researches quantified the effect of privatization on efficiency of firms by contrasting performance of those after privatization with non-privatized ones in the same surveyed periods. (Pohl et al., 1997; Fryman et al., 1999; Claessens \& Djankov, 2002). Most of these studies applied fairly large sample size of privatized and SOEs in eastern and central Europe to their estimation of the privatization effects on revenue performance, productivity, and the number of employees of the firms. Pohl et al. (1997) documented that the level of productivity growth among privatized firms is five times higher than that of still SOEs during a period of at least four years. Meanwhile, Frydman et al. (1999) clarified a reduction in performance of both privatized and SOEs in the first stage of restructuring, yet the privatized enterprises were shown to outperform the state ones. According to Claessens and Djankov (2002), conclusive evidence was found for better improvements in the performance of privatized businesses, in terms of sales revenues and labor productivity, and particularly the privatized ones reflected fewer job losses $(6.11 \%)$ than SOEs $(7.42 \%)$.

Earlier studies regarding ownership structure and corporate governance effects on privatized enterprises' performance

Over the past few decades there have been quite many investigations into the effects of ownership structure and corporate governance on privatized enterprises' behaviors. Some pointed out that those with concentrated ownership, after the privatization process, reflect more substantial improvement in their performance than those with dispersed ownership (Weiss \& Nikitin, 1998; Claessens \& Djankov, 1999a; Dean \& Andreyeva, 2001; Pivovarsky, 2001). Furthermore, Weiss and Nikitin (1998) showed significant empirical evidence of the level of ownership concentration of large shareholders with its positive correlation with increases in all indicators of effectiveness, but the concentrated ownership by investment funds do not help improve firms' performance. Pivovarsky (2001) posited that privatized enterprises with concentrated ownership by foreign 
companies and banks have more effective performance than those having concentrated ownership by domestic investors. Contrary to those findings, Dean and Andreyeva (2001) argued that concentrated ownership by corporate insiders will assist in more efficient operating performance. Moreover, analysis of Walsh and Whelan (2001) revealed that control by outside investors results in more efficient performance than control by insiders of the company or SOEs. According to Claessens and Djankov (1999b), the appointment of new directors among the enterprises after privatization will bring about higher profit margins and labor productivity.

Concerning the equitization programs in Vietnam, Truong, Lanjouw, and Lensink (2006) used a dataset of 121 equitized SOEs and 84 non-equitized SOEs for the 19932002 period to estimate the equitization impact on firm performance. Employing prepost comparison and difference in differences (DID) approaches, the authors detected post-equitization increases in profitability (as measured by ratio of income before tax to total assets, ratio of income before tax to total revenue, and ratio of income before tax to equity capital), sales revenue, and employee income (significant at $1 \%$ level for all). Additionally, derived from statistical testing results, their conclusion was that the equitization programs cause no changes to leverage ratio and the number of employments. The regression analyses also ascribe improvements in firm performance to several factors, including the level of state ownership, corporate governance, firm size, and stock-market listing.

Ngo et al. (2015) inspected the effectiveness of equitization using a dataset of 309 SOEs equitized in 2006. They applied two econometrical approaches including DID with controlled variables and PSM approaches, which were reportedly to remedy the shortcomings in other former studies like little control of selection bias and the deficiency in separation of the privatization impact from the simultaneous impacts exerted by other factors. The privatization or equitization was suggested in this study to enhance firms' profitability.

In short, empirical researches agreed on the positive effect of privatization (or equitization in the Vietnam's circumstance) on operating performance of enterprises. Besides this, there has been evidence of ownership structure and corporate governance regarded as key determinants of performance improvements after equitization. Nevertheless, methodological downsides could be found of most of the reviewed literature. For instance, the pre-post comparison technique, despite its credibility for 
measuring the impact of privatization on corporate performance, fails to single out other concurrent effects on the performance. Furthermore, the choice of with-without comparison method (to compare privatized firms' performance with that of SOEs), or even the DID approach, suffers bias in sample selection. In many countries, especially in Vietnam, businesses included in the list for equitization are usually chosen not randomly but according to pre-determined criteria depending on the economic, political, and social objectives at each stage of development. The inadequacy of methodology may lead to bias in research findings. Ngo et al. (2015), in spite of their attempt to overcome such by utilizing PSM, examined a group of equitized companies in 2006 yet faced difficulties in controlling for the simultaneous influences of variables pertaining to the change in the managerial system as well as ownership on business efficiency.

In this study we adopt the PSM method, which enables the matching between equitized enterprises in the treatment group and non-equitized SOEs with similar characteristics in the control group. The method is then followed by DID, which is applied to the two groups of equitized and non-equitized enterprises, and which, if employed solely, may cause the bias as discussed. Accordingly, when using the DID for two different paired groups, we seek to capitalize the merits of both the approaches, which distinguishes our own from other studies.

\section{Data and methodology}

\subsection{Research data}

We derive our panel dataset for the 2005-2012 period from a series of enterprise surveys conducted by GSO between 2005 and 2012. It covers financial statistics and some other information related to enterprises of different kinds in Vietnam. While the treatment group features the equitized SOEs, non-equitized ones are included in the control group of our sample over the period of 2007-2010.

We base our determination of the treatment group on change in the type of business over years. As such, those which had its type shifted from state ownership (central SOEs, local SOEs, central single-member limited liability companies of which $100 \%$ of charter capital is held by the state, and local single-member limited liability companies of which 100\% charter capital is held by the state) in 2006 to joint ownership (joint-stock companies, limited liability companies of which over $50 \%$ of charter capital is held by the state, non-state-owned joint-stock companies, and joint-stock companies of which 
under 50\% of charter capital is held by the state) in 2007 are defined as equitized enterprises in 2007. This technique is similarly applicable to equitized enterprises in 2008, 2009, and 2010. As a result, included in the treatment group are a total of 301 enterprises, among which there are 116, 52, 64, and 69 firms that were equitized in 2007, 2008, 2009, and 2010 respectively.

The control group involves 127 still SOEs in the 2007-2010 period. To estimate the impact of equitization on corporate performance, we compute the average value of each financial indicator for both pre-equitization years ( $\mathrm{t}-2$ and $\mathrm{t}-1)$ and post-equitization years $(t+1$ and $t+2)$.

\subsection{Sample structure}

According to Decree No. 44/1998/ND-CP issued in June 1998 and Decree No. 64/2002/ND-CP, issued in June 2002, selected for equitization should be central SOEs, local SOEs, and other SOEs. In our sample more than $90 \%$ of SOEs equitized in the 2007-2010 period are central and local ones. Central and local limited liability companies equitized in the surveyed periods make up a rather small proportion (about $10 \%)$.

\section{Table 1}

Sample structure by business types before equitization

\begin{tabular}{lccccccccc}
\hline \multirow{2}{*}{ Business type } & \multicolumn{7}{c}{ Year of equitization } \\
\cline { 2 - 10 } & \multicolumn{2}{c}{2007} & \multicolumn{2}{c}{2008} & \multicolumn{2}{c}{2009} & \multicolumn{2}{c}{2010} \\
\cline { 2 - 10 } & $\begin{array}{c}\text { No. of } \\
\text { firms }\end{array}$ & $\%$ & $\begin{array}{c}\text { No. of } \\
\text { firms }\end{array}$ & $\%$ & $\begin{array}{c}\text { No. of } \\
\text { firms }\end{array}$ & $\%$ & $\begin{array}{c}\text { No. of } \\
\text { firms }\end{array}$ & $\%$ \\
\hline Central SOE & 62 & 53.4 & 25 & 48.1 & 39 & 60.9 & 30 & 43.5 \\
Local SOE & 48 & 41.4 & 22 & 42.3 & 25 & 39.1 & 31 & 44.9 \\
Central limited & 5 & 4.3 & 4 & 7.7 & 0 & 0.0 & 4 & 5.8 \\
liability company & 1 & 0.9 & 1 & 1.9 & 0 & 0.0 & 4 & 5.8 \\
$\begin{array}{l}\text { Local limited } \\
\text { liability company }\end{array}$ & 116 & 100.0 & 52 & 100.0 & 64 & 100.0 & 69 & 100.0 \\
\hline Total & & & & & & & & \\
\hline
\end{tabular}

Source: Enterprise survey data for 2005-2012 (GSO) 
After equitization SOEs were to be converted into joint-stock firms; limited liability companies of which more than $50 \%$ of charter capital is owned by the state accounted for a relatively high proportion (48-61\%) in the studied period. There was an inclination, among the enterprises, to be shifted toward non-state-owned joint-stock ones between 2007 and 2010, whereas there was a tendency for the number of companies converted to joint-stock ones with $50 \%$ of state owned charter capital or lower to dwindle within the same period.

\section{Table 2}

Sample structure by the level of state ownership after equitization

\begin{tabular}{|c|c|c|c|c|c|c|c|c|}
\hline \multirow{3}{*}{ Business type } & \multicolumn{8}{|c|}{ Year of equitization } \\
\hline & \multicolumn{2}{|c|}{2007} & \multicolumn{2}{|c|}{2008} & \multicolumn{2}{|c|}{2009} & \multicolumn{2}{|c|}{2010} \\
\hline & $\begin{array}{l}\text { No. of } \\
\text { firms }\end{array}$ & $\%$ & $\begin{array}{l}\text { No. of } \\
\text { firms }\end{array}$ & $\%$ & $\begin{array}{l}\text { No. of } \\
\text { firms }\end{array}$ & $\%$ & $\begin{array}{l}\text { No. of } \\
\text { firms }\end{array}$ & $\%$ \\
\hline $\begin{array}{l}\text { Joint-stock and } \\
\text { limited liability } \\
\text { companies with over } \\
50 \% \text { of state charter } \\
\text { capital }\end{array}$ & 71 & 61.2 & 30 & 57.7 & 31 & 48.4 & 42 & 60.9 \\
\hline $\begin{array}{l}\text { Joint-stock } \\
\text { companies with } 50 \% \\
\text { of state charter } \\
\text { capital or less }\end{array}$ & 31 & 26.7 & 14 & 26.9 & 13 & 20.3 & 13 & 18.8 \\
\hline $\begin{array}{l}\text { Joint-stock } \\
\text { companies with } 0 \% \\
\text { of state charter } \\
\text { capital }\end{array}$ & 14 & 12.1 & 8 & 15.4 & 20 & 31.3 & 14 & 20.3 \\
\hline Total & 116 & 100.0 & 52 & 100.0 & 64 & 100.0 & 69 & 100.0 \\
\hline
\end{tabular}

Source: Enterprise survey data for 2005-2012 (GSO)

\subsection{Methodology}

As discussed above, certain limitations could be recorded with pre-post and withwithout comparison approaches as well as the DID technique in measuring the impact of privatization (equitization) on firm performance. To remedy those shortcomings, we 
seek to employ, in combination with DID, the PSM, which has been devised to produce treatment and control groups in a similar fashion based on the propensity score of each sampled individual.

The propensity score is defined on the basis of characteristics of each individual by the logit model. Each of the treated individuals in the treatment group are matched with that in the control group with the similar propensity score and are then compared with each other. The difference between the treatment group's individual and the control group's counterpart is the impact of policy or program. One advantage of this technique is the outstanding ability to control for biases in sampling (for unrandomly selected sample). After the matching, we proceed with the DID approach in addition to comparing average values of the indicators of performance between the two paired groups for further comparison in order to capitalize on the merits of both techniques.

To estimate the propensity score, we employ the logit model for each year of equitization. The dependent variable is a binary one (it takes the value of 1 if firm is an equitized SOE, and takes the value of 0 if firm is a still SOE). The dependent variable includes two variables of years of operation and firm size, whose average values of two years prior to equitization are taken. Firm size is measured by the number of employees per firm in logarithm (Ngo et al., 2005). Based on propensity scores, which have been calculated to match individuals in the treatment group with those in the control group with similar propensity scores (adopting the caliper matching method $(0,1)$ ), we pair individuals with similar characteristics. The difference in their propensity scores must fall within the allowed range, which is, in this case, $0-1$. Afterward, we calculate the values that reveal effects of the impact policy (equitization) through comparing indicators of the performance after equitization between the treatment and control groups.

Also, we apply the DID estimation to the studied sample with some of its good points involving eliminating the impact of the time factor on corporate performance (over time enterprises may gain more experience, and therefore their operations are more efficient) and removing the effects on performance derived from the change of macro factors (deeper trade liberalization or greater development of the national financial market). Since this technique has been previously employed merely for treatment and control groups without pair matching, analysis of the policy impact would rely on the average values of the changes in indicators calculated for these two groups. If the value range 
considered is too large, then it will be more likely to result in biases in the estimated results. Our adaptation may be regarded a significant contribution as compared with earlier studies in the same field.

Changes in corporate performance before and after equitization are measured with DID approach as displayed in Table 3. Two-year averages of the indicators before and after equitization programs of each group are calculated in advance, and then we take and finally calculate the differences of the pre- and post-equitization values for both treatment and control groups. Using this method we derive the achieved results from the comparison of changes in the indicators as reflected by each group.

\section{Table 3}

The DID analysis

\begin{tabular}{|c|c|c|c|c|}
\hline & $\begin{array}{l}\text { Two-year pre- } \\
\text { equitization } \\
\text { average of the } \\
\text { indicator }\end{array}$ & $\begin{array}{c}\text { Two-year } \\
\text { post- } \\
\text { equitization } \\
\text { average of the } \\
\text { indicator }\end{array}$ & $\begin{array}{c}\text { Pre- and post- } \\
\text { equitization } \\
\text { difference }\end{array}$ & $\begin{array}{l}\text { Pre- and post- } \\
\text { equitization } \\
\text { difference } \\
\text { between treatment } \\
\text { group and control } \\
\text { group }\end{array}$ \\
\hline Treatment group & $\mathrm{PS}(0)$ & $\mathrm{PS}(1)$ & $\mathrm{DS}=\mathrm{PS}(1)-\mathrm{PS}(0)$ & \\
\hline Control group & $\mathrm{PG}(0)$ & PG(1) & $\begin{array}{c}\mathrm{DG}=\mathrm{PG}(1)- \\
\mathrm{PG}(0)\end{array}$ & $\mathrm{DPG}=\mathrm{DS}-\mathrm{DG}$ \\
\hline
\end{tabular}

While the treatment group includes the SOEs equitized in the period of 2007-2010, non-equitized ones are incorporated into the control group. A few of the following financial indicators are used to measure firm performance: income before tax as a ratio to total assets (IBTA), income before tax as a ratio to sales (IBTS), income before tax as a ratio to equity capital (IBTE), total asset turnover, labor productivity, debt ratio, and number of employees. The purpose of utilizing income before tax instead of after tax is to remove the effect of corporate income tax in comparing firms' operating performance (favorable tax rates might have been offered to some companies that invest in the industry or location covered under the related policy). Financial indicators measuring corporate performance and their expected variance after equitization are detailed in Table 4. 


\section{Table 4}

Corporate performance indicators and their expected variance

\begin{tabular}{lll}
\hline Indicator & \multicolumn{1}{c}{ Interpretation } & $\begin{array}{c}\text { Expected } \\
\text { variance }\end{array}$ \\
\hline $\begin{array}{l}\text { Income before tax to total asset ratio } \\
\text { (IBTA) }\end{array}$ & $\begin{array}{l}\text { Income before tax/total assets } \\
\text { Income before tax to sales ratio (IBTS) }\end{array}$ & $\begin{array}{l}\text { Income before tax/sales } \\
\text { Income before tax to equity }\end{array}$ ratio \\
(IBTE) & Income before tax/equity capital & Increasing \\
Total asset turnover (VQTS) & Net sales/total assets & Increasing \\
Labor productivity (NSLD) & Total sales/total employment & Increasing \\
Debt ratio & Total debt/total assets & Increasing \\
& Number of employees at the end of & Decreasing \\
the year & Decreasing \\
\hline
\end{tabular}

Drawing on previous findings, we expect improvements in the indicators of corporate performance after privatization due to the three following reasons. First, the process itself would focus the management on the profit related objectives rather than others since senior managers, after the privatization, are supposed to take direct responsibility toward shareholders (Yaroow, 1986). Second, along with the process, business ownership is transferred from the state management agencies to firms' directors; therefore, there would be improved business performance through the use of a logical number of employees available of the firm as well as the adoption of reasonable compensation policy (Boycko et al., 1996). Third, more effectively, enterprises utilize capital resources, equipment, and technology thanks to no more state subsidies (Kikeri et al., 1992; Boycko et al. 1996).

In addition, the debt ratio is expected to reduce after equitization. There are often more incentives for SOEs to borrow from the state banking system and to receive the government's debt guarantees. For private enterprises, investment decisions should follow the principle that the expected rate of marginal investment returns must offset the marginal cost of capital, and the cost of capital is the weighted average between return on equity and cost of capital at market prices. Enterprises during post-equitization 
periods must operate in line with market conditions when deciding on their levels of investment or capital mobilization methods. The cost of capital may increase when there are no longer the government's guarantees of different kinds of debt, and excessive borrowing would thus lead to increased risk of insolvency. Also, in the form of jointstock enterprises they have another channel to mobilize at lower cost of capital, i.e. from investors in the capital market. From the aforementioned reasons, we argue that it is likely for the capital restructuring toward reducing the borrowing rate after the equitization. Many previous studies, such as Mathur and Banchuenvijit (2007), Omran (2004), and Sun and Tong (2002), have shown evidence of the reduced post-equitization debt ratio.

We also assume a decline in the number of employees. Besides their aiming at profitable activities, SOEs have to fulfil a range of socioeconomic objectives proposed by the State. Hence, a high rate of employment can be maintained before privatization. After the process, however, due to no more support from the State, these firms have to restructure their employment to fix the operations for profit maximization, which probably causes a reduced number.

Furthermore, improvements in corporate performance as triggered by equitization are expected, and they may vary among different groups of enterprises. For this reason, in the next step we categorize our surveyed sample into pairs based on the criteria which are presumed to have effects on the post-equitization performance of firms.

Initially, two groups of joint-stock firms are to include large-sized and small/medium-sized ones based on the average number of employees for two preequitization years. In accordance with Decree No. 90/2001/ND-CP issued by the Government, those with the registered capital of less than VND10 billion or the annual average number of employees of less than 300 are classified as small- and medium-sized enterprises. Small and medium-sized companies will make better improvements in their operating efficiency compared to big ones due to favorable conditions prevailing for their restructuring and business adjustments.

In addition, the degree of shares held by the state in small-sized equitized firms is often less than that among large-sized ones. Many works, nevertheless, have indicated that a certain percentage of state-owned shares in these have a negative influence on post-equitization performance of the firms. 
The findings of the previously published works suggested a pivotal role of ownership structure among joint-stock companies in improving their performance after equitization. To measure this impact, we classify the surveyed enterprises into two groups by years of equitization: (i) those whose two-year post-equitization average rate of state ownership is lower than the median of this indicator; and (ii) those whose two-year post-equitization average rate of state ownership is equal to or higher than its median level. The medians of two-year post-equitization average rate of state ownership for 2007, 2008, 2009, and 2010 in this case are 58\%, 51\%, 40\%, and $50 \%$ respectively. We expect better improvement in firm performance of Group 1.

\section{Research results}

4.1. Impact of equitization on firm performance in terms of the entire research sample

As have been mentioned, the originality of this research is the matching of equitized enterprises with non-equitized ones that have similar characteristics, and in this circumstance, by firm size and years of operation. We then estimate the impact of equitization through comparing performance of the firms in these two groups. Specifically, after the matching using PSM approach (the avarage value of firm size and years of operation before equitization applied to estimate the propensity score), a comparision is made between two-year post-equitization averages of the indicators of firm perfomance for the group of equitized enterprises (treatment group) and those for non-equitized enterprises (control group). Next, to take advatage of the used approaches, based on the paired research sample and using DID technique, we perform another comparison of pre-/post-equitization different values between the treatment and control groups for each year. Table 5 provides the results of PSM and DID analyses. 


\section{Table 5}

Estimated results using PSM and DID approaches

\begin{tabular}{lcccccccc}
\hline \multirow{2}{*}{ Indicator } & \multicolumn{2}{c}{2007} & \multicolumn{2}{c}{2008} & \multicolumn{2}{c}{2009} & \multicolumn{2}{c}{2010} \\
\cline { 2 - 8 } & PSM & DID & PSM & DID & PSM & DID & PSM & DID \\
\hline Profitability & & & & & & & & \\
IBTA & 0.012 & 0.008 & 0.001 & -0.032 & $0.065^{* * *}$ & $0.036^{*}$ & $0.035^{*}$ & 0.077 \\
IBTE & -0.012 & -0.005 & -1.045 & -0.577 & 0.063 & -0.066 & 0.006 & 0.021 \\
IBTS & $0.215^{*}$ & $0.228^{* *}$ & 0.03 & 0.015 & $0.098^{* *}$ & 0.027 & 0.220 & 0.175 \\
VQTS & $-1.658^{* *}$ & $-0.690^{*}$ & $-1.448^{* * *}$ & -0.484 & $-1.349^{* * *}$ & -0.413 & -1.173 & 0.134 \\
NSLD & -185 & 215 & -460 & -136 & 452 & 815 & 159 & 349 \\
Debt ratio & -0.043 & -0.039 & -0.094 & -0.077 & $-0.169^{* *}$ & $-0.082^{*}$ & -0.237 & -0.154 \\
No. of employees & -73 & $-65^{* *}$ & -121 & $-128^{*}$ & -4 & -23 & -2 & -79 \\
\hline
\end{tabular}

Note: ***, **, and $*$ denote significance levels of $1 \%, 5 \%$, and $10 \%$ respectively.

\section{Profitability}

Profitability is an essential indicator to the measurement of corporate performance. The results using PSM reveal that the enterprises equitized in the years of 2007, 2009, and 2010 have higher profitability (IBTA and IBTS) than nonequitized ones. Particularly, the average IBTS during 2008-2009 of 2007's equitized firms is $21.5 \%$ higher than non-equitized SOEs with the same characteristics (this indicator increases by $9.8 \%$ correspondingly for 2009's equitized enterprises). The IBTAs after equitization of 2009 and 2010's equitized enterprises are higher than those of non-equitized ones (6.5\% and $3.5 \%$ respectively).

The results of DID analysis show that the level of variance in the ratio of income before tax to sales (IBTS) before and after equitization of the group of 2007's equitized enterprises is $6.8 \%$ higher than that of non-equitized SOEs (this figure is $3.6 \%$ for 2009's equitized enterprises). These results partially confirm the positive impact of equitization on the profitability of equitized firms in Vietnam. 
Many scholars argued for a drop in the debt ratio after the corporate equitization process since firm's retained earnings could be higher, and more shares, issued by the firm for additional capital mobilization as and when needed. In Vietnam we figure out the reducing debt ratio, which is statistically significant for the year 2009. To be precise, two-year post-equitization average of debt ratio of 2009's equitized enterprises decreases by $16.9 \%$ as compared to non-equitized SOEs (PSM method). The change in the pre-/post-equitization debt ratio of 2009's equitized SOEs is $6.9 \%$ lower than that of non-equitized ones (DID method). Thus, these results provide further evidence of equitization impact on the post-equitization debt ratio of firms. After the process, with no more preferential policies on loan access, a few companies have changed their capital structure by reducing the debt ratio and utilizing other sources with lower costs of capital such as issuance of more shares.

\section{Number of employees}

The impact of privatization on firms' employment situation having been reported in previous research is still vague. Some studies (Megginson et al., 1994; Boubakri \& Cosset, 1998) pointed out that after privatization there is an increase in the number of employees among corporations while others (La Porta \& López-De- Silanes, 1999; Harper, 2002) documented that privatization has led to a significant decline. The results of this study are quite consistent with conclusion of La Porta and López-de-Silanes (1999) and Harper (2002), who implied a post-equitization reduced number of employees. This change is statistically significant upon the utilization of DID approach for the 2007's and 2008's equitized firms. Specifically, the pre- and post-equitization number of employees of 2007's equitized SOEs is 65 people fewer than that of nonequitized ones, whereas this figure is 128 people for 2009's enterprises. The number of employees decreasing after equitization could be the result of labor restructuring in order to maintain a reasonable level of employment among the firms.

\section{Asset turnover and labor productivity}

The results in Table 5 show that the levels of post-equitization labor productivity of 2007's, 2008's, and 2010's equitized enterprises are higher than those of non-equitized ones with the same characteristics. For the case of 2009's equitized SOEs, their figure is lower than that of non-equitized ones. However, this change is not statistically significant. Moreover, contrary to our expectation, the volumes of asset turnover are 
suggested to drop after equitization for those equitized in 2007, 2008, and 2009, as compared to those which have never been equitized.

\subsection{Impact of equitization on firm performance in terms of groups of enterprises}

\subsubsection{Impact of equitization on firm performance by firm size}

In this section, to determine whether there exists any difference in the impact of equitization on the performance of large-sized and small- and medium-sized enterprises, we categorize them into two groups based on the two-year pre-equitization average number of employees. The small- and medium-sized ones are expected to improve their performance better than the large-sized firms since they would be more convenient to implement restructuring and business schemes than the others. It is revealed by the results of Tables 6 and 7 that similar levels of equitization impact are produced on performance of both types of firms, which is also consistent with the findings for the whole researched sample.

\section{Table 6}

Results of PSM and DID analyses of large-sized equitized enteprises

\begin{tabular}{lcccccccc}
\hline \multirow{2}{*}{ Indicator } & \multicolumn{2}{c}{2007} & \multicolumn{2}{c}{2008} & \multicolumn{2}{c}{2009} & & 2010 \\
\cline { 2 - 8 } & PSM & DID & PSM & DID & PSM & DID & PSM & DID \\
\hline Profitability & & & & & & & & \\
IBTA & 0.012 & 0.007 & -0.002 & 0.017 & $0.059 *$ & 0.014 & 0.026 & 0.053 \\
IBTE & -0.819 & -0.473 & -1.151 & -2.041 & -0.376 & 0.275 & 0.153 & 0.169 \\
IBTS & $0.056^{*}$ & $0.068^{* *}$ & 0.064 & 0.077 & $0.097 *$ & 0.100 & 0.357 & 0.394 \\
VQTS & -0.180 & $-0.975^{* *}$ & $-1.597 * *$ & $-0.692^{*}$ & 0.330 & -0.454 & -0.668 & -1.055 \\
NSLD & 186 & 435 & -689 & -148 & 321 & 565 & 764 & 514 \\
Debt ratio & 0.027 & 0.015 & 0.047 & -0.036 & $-0.299^{* *}$ & $-0.273 * * *$ & -0.069 & -0.082 \\
No. of employees & 35 & $-112^{*}$ & -163 & $-287^{* *}$ & -53 & -53 & 37 & 66 \\
\hline
\end{tabular}

Note: $* * *, * *$, and $*$ denote significance levels of $1 \%, 5 \%$, and $10 \%$ respectively. 


\section{Table 7}

Results of PSM and DID analyses of small- and medium-sized equitized enteprises

\begin{tabular}{lcccccccc}
\hline \multirow{2}{*}{ Indicator } & \multicolumn{2}{c}{2007} & \multicolumn{2}{c}{2008} & \multicolumn{2}{c}{2009} & \multicolumn{2}{c}{2010} \\
\cline { 2 - 8 } & PSM & DID & PSM & DID & PSM & DID & PSM & DID \\
\hline Profitability & & & & & & & & \\
IBTA & -0.027 & -0.043 & 0.007 & -0.056 & $0.045^{*}$ & $0.050^{*}$ & 0.013 & -0.016 \\
IBTE & 0.244 & -0.110 & 0.027 & 0.053 & 0.107 & 0.014 & 0.004 & -0.326 \\
IBTS & 0.758 & 0.379 & 0.108 & 0.170 & $0.089^{* *}$ & 0.068 & 0.044 & -0.041 \\
VQTS & $-1.461 *$ & -0.188 & $-1.314^{*}$ & -0.230 & $-3.140^{* *}$ & -0.667 & 0.465 & -0.032 \\
NSLD & $-588^{* *}$ & -93 & -92 & -395 & -849 & -92 & 441 & 14 \\
Debt ratio & $-0.062^{* *}$ & -0.126 & -0.131 & -0.064 & -0.128 & -0.024 & $-0.303 * *$ & -0.092 \\
No. of employees & 7 & 12 & -20 & -11 & -36 & $-38^{* *}$ & 36 & 23 \\
\hline
\end{tabular}

Note: $* * *, * *$, and $*$ denote significance levels of $1 \%, 5 \%$, and $10 \%$ respectively.

4.2.2. Impact of equitization on firm performance by ownership structure

Earlier findings indicate the proportion of shares held by the state among equitized enterprises is negatively associated with post-equitization firm performance. To measure such an effect, as discussed, we have divided our sample into two groups by years of equitization: (i) those having the two-year post-equitization average rate of state ownership which is lower than the median of this indicator; and (ii) those having the two-year post-equitization average rate of state ownership which is equal to or higher than its median level. The first is expected to exhibit better improved performance than the second.

Due to data constraints regarding the second group, we could only estimate the equitization impact on 2007's equitized firms. The statistical results of Table 8 display no effect of equitization on profitability of equitized SOEs with high levels of state ownership.

Still, the results in Table 9 clarify positive effects of equitization on profitability of equitized enterprises whose two-year post-equitization average of state ownership is 
lower than the median level during the whole surveyed period (2007-2010) This can be attributed to the fact that the existence of state's shareholdings in equitized firms results in increased agency costs (e.g., for interference in usual business activities, more political and social objectives must be considered alongside profit maximization). So, regarding equitized businesses, the lower the rate of state ownership, the greater the improvements in their post-equitization performance. Moreover, several similarities to the case of the whole studied sample can be confirmed of the findings for the equitization impacts on other indicators (total asset turnover, labor productivity, debt ratio, and number of employees) among the two groups of firms categorized by ownership structure.

\section{Table 8}

Results of PSM and DID analyses of equitized enterprises with high rates of state ownership

\begin{tabular}{lcc}
\hline & & 2007 \\
Indicator & PSM & DID \\
\cline { 2 - 3 } Profitability & & \\
IBTA & -0.004 & -0.008 \\
IBTE & -0.079 & -0.047 \\
IBTS & 0.171 & 0.137 \\
VQTS & $-1.253^{*}$ & -0.496 \\
NSLD & 22 & 274 \\
Debt ratio & -0.020 & -0.052 \\
No. of employees & -120 & -81 \\
\hline
\end{tabular}

Notes: Due to an extremely small number of firms incorporated in the control group for 2008-2010 period, they cannot be matched in accordance with the proposed method.

$* * *, * *$, and $*$ denote significance levels of $1 \%, 5 \%$, and $10 \%$ respectively. 


\section{Table 9}

Results of PSM and DID analyses of equitized enterprises with low rates of state ownership

\begin{tabular}{lcccccccc}
\hline \multirow{2}{*}{ Indicator } & \multicolumn{2}{c}{2007} & \multicolumn{2}{c}{2008} & \multicolumn{2}{c}{2009} & \multicolumn{2}{c}{2010} \\
\cline { 2 - 9 } & PSM & DID & PSM & DID & PSM & DID & PSM & DID \\
\hline Profitability & & & & & & & & \\
IBTA & $0.035^{*}$ & $0.097^{*}$ & $0.045^{*}$ & $0.034^{*}$ & $0.050^{* *}$ & 0.021 & $0.035^{*}$ & 0.077 \\
IBTE & -0.067 & -0.078 & -0.215 & 0.916 & 0.046 & 0.073 & 0.006 & 0.021 \\
IBTS & 0.027 & $0.251^{*}$ & -0.080 & -0.081 & $0.119^{* * *}$ & $0.053^{*}$ & 0.220 & 0.174 \\
VQTS & -1.042 & 0.225 & $-1.709^{* * *}$ & $-0.789^{*}$ & $-1.370^{* * *}$ & -0.694 & -1.173 & 0.134 \\
NSLD & -1054 & -13 & $-924^{* * *}$ & -641 & -692 & -174 & 158 & 349 \\
Debt ratio & $-0.306^{*}$ & -0.316 & -0.012 & -0.045 & $-0.173^{*}$ & -0.057 & -0.237 & -0.154 \\
No. of employees & 482 & 53 & 18 & -66 & 69 & 66 & -3 & -79 \\
\hline
\end{tabular}

Note: $* * *, * *$, and $*$ denote significance levels of $1 \%, 5 \%$, and $10 \%$ respectively.

\section{Conclusion}

This research aims to investigate the impact of equitization on performance of Vietnam's enterprises by using GSO's enterprise survey data. The sample includes 301 SOEs that were equitized in the period of 2007-2010 and 127 non-equitized ones. One of its outstanding points is the matching between equitized and non-equitized firms having several characteristics in common, and in this circumstance, by firm size and years of operation. Afterward, we evaluate the equitization effects via the comparison of the performance as reflected by the two groups of enterprises. In order to capitalize on the merits of both the methods (PSM and DID), we proceed to compare pre- and postequitization values of the treatment and control groups by each year, using the DID approach.

The empirical results demonstrate a significant increase in firms' post-equitization ratios of income before tax to total assets and income before tax to sales, which reinforces the hypothesis that firm performance can be improved after the process. Furthermore, this paper provides empirical evidence consistent with the findings of $\mathrm{La}$ Porta and López-De-Silanes (1999) and Harper (2002), who detected a diminishing post- 
equitization number of employees. This change becomes statistically significant when we apply the DID technique to 2007's and 2008's equitized firms, confirming the fact that improved performance of equitized enterprises is partly derived from dismissal of redundant personnel among these firms. A reduction in firms' debt ratio is also found in this study

\section{References}

Boubakri, N., \& Cosset, J.-C. (1998). The financial and operating performance of newly privatised firms: Evidence from developing countries. Journal of Finance, 53(3), 1081-1110.

Boubakri, N., \& Cosset, J.-C. (2002). Does privatisation meet the expectations in developing countries? A survey and some evidence from Africa. Journal of African Economies, 11(1), 111140.

Boubakri, N., Cosset, J.-C., \& Guedhami, O. (2004). Privatisation, corporate governance and economic environment: Firm-level evidence from Asia. Pacific-Basin Finance Journal, 12(1), 65-90.

Boycko, M., Shleifer, A., \& Vishny, R. W. (1996). A theory of privatisation. Economic Journal, 106(435), 309-319.

Claessens, S., \& Djankov, S. (1999a). Ownership concentration and corporate performance in the Czech Republic. Journal of Comparative Economics, 27(3), 498-513.

Claessens, S., \& Djankov, S. (1999b). Enterprise performance and management turnover in the Czech Republic. European Economic Review, 43(4-6), 1115-1124.

Claessens, S., \& Djankov, S. (2002). Privatization benefits in Eastern Europe. Journal of Public Economics, 83(2002), 307-324.

Dean, J. W., \& Andreyeva, T. (2001). Privatisation, ownership structure and company performance: The case of Ukraine. Journal for Institutional Innovation, Development and Transition, 5, 62-72.

Dewenter, K. L., \& Malatesta, P. H. (2001). State-owned and privately owned firms: An empirical analysis of profitability, leverage, and labor intensity. The American Economic Review, 91(1), 320-334.

D’Souza, J., \& Megginson, W. L. (2001). The financial and operating performance of privatised firms during the 1990s'. The Journal of Finance, 54(4), 1397-1438.

Frydman, R., Gray, C., Hessel, M., \& Rapaczynski, A. (1999). When does privatization work? The impacts of private ownership on corporate performance in the transition economies. Quarterly Journal of Economics, 114(4), 1153-1191.

Harper, J. T. (2002). The performance of privatized firms in the Czech Republic. Journal of Banking \& Finance, 26(4), 621-649. 
Kikeri, S., Nellis, J., \& Shirley, M. (1992). Privatisation: The lessons of experience. Washington, DC: The World Bank. Retrieved from http://documents.worldbank.org/curated/en/1992/08/ 440510/privatization-lessons-experience

La Porta, R., \& López-de-Silanes, F. (1999). The benefits of privatisation: Evidence from Mexico. Quarterly Journal of Economics, 114(4), 1193-1241.

Mathur, I., \& Banchuenvijit, W. (2007). The effects of privatization on the performance of newly privatized firms in emerging markets. Emerging Markets Review, 8(2), 134-146.

Megginson, W. L., Nash, R. C., \& van Randenborgh, M. (1994). The financial and operating performance of newly privatised firms: An international empirical analysis. The Journal of Finance, 49(2), 403-452.

Megginson, W. L., \& Netter, J. M. (2001). From state to market: A survey of empirical studies on privatisation. Journal of Economic Literature, 39(2), 321-389.

Ngo, M. T., Nonneman, W., \& Jorissen, A. (2015). Privatization of Vietnamese firms and its effects on firm performance. Asian Economic and Financial Review, 5(2), 202-217.

Omran, M. (2004). The performance of state-owned enterprises and newly privatized firms: Does privatization really matter? World Development, 32(6), 1019-1041.

Parker, D., \& Kirkpatrick, C. (2005). Privatisation in developing countries: A review of the evidence and the policy lessons. Journal of Development Studies, 41(4), 513-541.

Pivovarsky, A. (2001). How does privatization work? Ownership concentration and enterprise performance in Ukraine (IMF Working Paper WP/01/42). Washington, DC: International Monetary Fund.

Pohl, G., Anderson, R. E., Claessens, S., \& Djankov, S. (1997). Privatization and restructuring in Central and Eastern Europe: Evidence and policy options (World Bank Technical Paper, 368). Retrieved from SSRN: http://ssrn.com/abstract=37369 or http://dx.doi.org/10.2139/ssrn.37369

Sun, Q., \& Tong, H. S. (2002). Malaysian privatization: A comprehensive study. Financial Management, 31(4), 79-105.

Truong, D. L., Lanjouw, G., \& Lensink, R. (2006). The impact of privatization on firm performance in a transition economy: The case of Vietnam. Economics of Transition, 14(2), 349-389.

Truong, D. L., Vo, V. D., \& Le, L. H. (2006). Impact of equitization on performance of enterprises in the Mekong River Delta (in Vietnamese). Economic Studies, No.332, 64-70.

Walsh, P., \& Whelan, C. (2001). Firm performance and the political economy of corporate governance: Survey evidence for Bulgaria, Hungary, Slovakia and Slovenia. Economic Systems, 25(2), 85-112.

Weiss, A., \& Nikitin, G. (1998). Performance of Czech companies by ownership structure (University of Michigan Davidson Institute Working Paper, 186). MI: William Davidson Institute at the University of Michigan.

Yarrow, G., King, M., Mairesse, J., \& Melitz, J. (1986). Privatisation in theory and practice. Economic Policy, 1(2), 323-377. 